\title{
Prevalence of underweight in children and adolescents (aged 3-18 years) from Kraków (Poland) in 1983 and 2010
}

\author{
Małgorzata Kowal ${ }^{1, *}$, Renata Woźniacka ${ }^{2}$, Aneta Bac $^{3}$ and Ryszard Żarów ${ }^{1}$ \\ 'Department of Anthropology, Faculty of Physical Education, University of Physical Education, al. Jana Pawła II 78, \\ 31-571 Krakow, Poland: '2Department of Anatomy, Faculty of Motor Rehabilitation, University of Physical Education in \\ Krakow, Krakow, Poland: ${ }^{3}$ Department of Occupational Therapy, Faculty of Motor Rehabilitation, University of \\ Physical Education in Krakow, Krakow, Poland
}

Submitted 4 July 2018: Final revision received 12 March 2019: Accepted 19 March 2019

\begin{abstract}
Objective: To estimate the changes in the prevalence of underweight among girls and boys living in Kraków that occurred between 1983 and 2010.

Design: The study was based on two cross-sectional surveys conducted in 1983 and 2010. The prevalence of underweight was estimated based on the International Obesity Task Force (IOTF) and Centers for Disease Control and Prevention (CDC) cut-off points.

Setting: The study was conducted in Kraków, Poland.

Participants: Children aged 3-18 years ( $n$ 5245).

Results: Between 1983 and 2010 the prevalence of underweight decreased in both sexes. Using the IOTF criteria, the prevalence of underweight decreased from 10.5 to $10.3 \%$ in girls and from 8.9 to $7.5 \%$ in boys, but it was still higher in girls than in boys. According to the CDC criteria, this prevalence decreased from 5.1 to $4.4 \%$ and from 5.9 to $4.6 \%$, respectively, and was slightly lower in girls. According to the IOTF criteria, underweight prevalence increased slightly during childhood in both sexes while according to the CDC criteria it decreased in boys and did not change in girls. Among juveniles and adolescents, it decreased regardless of the method used. Conclusions: The frequency of underweight in the population of children and adolescents from Kraków changed slightly in 1983 and 2010 despite economic and social changes. Depending on the cut-off points used, not only the magnitude but also the direction of changes between series could be different. In order to aid global monitoring, the prevalence of underweight as well as overweight should always be evaluated by several methods.
\end{abstract}

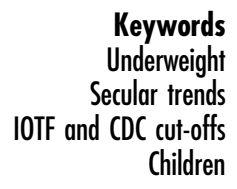

Over the past few decades, a dramatic increase in the prevalence of overweight and obesity not only among adults but also among children and adolescents has been documented in many Western European and other countries ${ }^{(1-3)}$. This caused concern among public health practitioners because childhood obesity increases the risk of obesity in adulthood ${ }^{(3-5)}$.

Screening studies on the nutritional status of children and adolescents in many populations around the world have shown that overweight is accompanied by the other and often overlooked problem of underweight, which also has a negative impact on the health of the population ${ }^{(6,7)}$. Apart from an increased risk of infectious diseases, lack of weight can also cause hair loss, hypothermia and even osteoporosis $^{(4)}$. Moreover, in girls it can result in menstrual disorders, secondary amenorrhoea and eating disorders (e.g. anorexia). In women of reproductive age, underweight may contribute to adverse pregnancy outcomes, intra-uterine growth retardation, premature birth, labour complications and even maternal death ${ }^{(8)}$.

The anthropometric index of relative body mass, i.e. BMI, is commonly used to classify underweight (BMI $\left.<18.5 \mathrm{~kg} / \mathrm{m}^{2}\right)^{(7)}$. Based on this index, it is estimated that in 2014 , almost $9 \%$ of men and almost $10 \%$ of women in the world were underweight. This percentage has declined considerably in the last 40 years: in 1975, the percentages were 13.8 and $14.6 \%$, respectively. The phenomenon of underweight is most common in South Asia at just over $24 \%$, compared with $34 \%$ in the 1970 s, whereas this phenomenon occurs rarely in Northwest and Southwest Europe (less than $1 \%$ in 2014 compared with 3\% in 1975$)^{(9)}$. 
Table 1 Summary of studies of changes in the prevalence of underweight in children and adolescents from different countries and regions by the International Obesity Task Force criteria

\begin{tabular}{|c|c|c|c|c|c|c|c|}
\hline & \multirow[b]{2}{*}{ Country/region } & \multirow[b]{2}{*}{ Years } & \multirow[b]{2}{*}{ Age range (years) } & \multicolumn{2}{|c|}{$\begin{array}{l}\text { Change in } \\
\text { prevalence of } \\
\text { underweight } \\
\text { in boys }(\%)\end{array}$} & \multicolumn{2}{|c|}{$\begin{array}{l}\text { Change in } \\
\text { prevalence of } \\
\text { underweight } \\
\text { in girls }(\%)\end{array}$} \\
\hline & & & & From & To & From & To \\
\hline \multirow{6}{*}{ Country } & Brazil(12) $^{(12}$ & 1974-1997 & $6-18$ & $18 \cdot 3$ & $10 \cdot 6$ & $11 \cdot 4$ & $6 \cdot 5$ \\
\hline & $\operatorname{Brazil}^{(36)}$ & $2005-2011$ & $7-14$ & $2 \cdot 1$ & 1.7 & 3.1 & 4.0 \\
\hline & China ${ }^{(12)}$ & $1991-1997$ & $6-18$ & $16 \cdot 9$ & 14.4 & $12 \cdot 0$ & 11.5 \\
\hline & France $^{(11)}$ & 2009-2013 & $9-16$ & $7 \cdot 1$ & $7 \cdot 3$ & $12 \cdot 0$ & $16 \cdot 7$ \\
\hline & Russia ${ }^{(12)}$ & 1992-1998 & $6-18$ & $9 \cdot 0$ & $7 \cdot 7$ & 4.9 & $8 \cdot 6$ \\
\hline & $U_{S A}^{(12)}$ & 1971/74-1988/94 & $6-18$ & $5 \cdot 2$ & 3.6 & $5 \cdot 0$ & 3.0 \\
\hline \multirow[t]{4}{*}{ Region } & China, Xiamen ${ }^{(34)}$ & 2009-2015 & 5 & $5 \cdot 7$ & $2 \cdot 2$ & $5 \cdot 3$ & 1.7 \\
\hline & China, Shandong ${ }^{(7)}$ & $1985-2010$ & $7-18$ & $18 \cdot 2$ & 9.8 & 23.5 & $15 \cdot 1$ \\
\hline & Poland, Lubelskie Voivodeship ${ }^{(15)}$ & $1986-2006$ & $7-20$ & $10 \cdot 0$ & $8 \cdot 0$ & 13.0 & $16 \cdot 0$ \\
\hline & Spain, Cuenca Province ${ }^{(10)}$ & 2004-2010 & $8-11$ & 9.5 & $8 \cdot 3$ & $9 \cdot 3$ & 7.9 \\
\hline \multirow[t]{3}{*}{ City in Poland } & Warszawa ${ }^{(49)}$ & $1971-2005 / 06$ & $7-18$ & 7.9 & $6 \cdot 4$ & $10 \cdot 4$ & 13.9 \\
\hline & 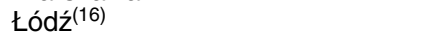 & 1977-2004 & $7-19$ & $7 \cdot 2$ & $12 \cdot 1$ & 11.0 & $20 \cdot 2$ \\
\hline & Kraków (present study) & $1986-2010$ & $3-18$ & $8 . \overline{9}$ & 7.5 & 10.5 & 10.4 \\
\hline
\end{tabular}

Among children and adolescents, the prevalence of underweight has not changed so rapidly in the corresponding period. It is estimated that in the period 1975-2016 underweight decreased from 14.8 to $12.4 \%$ among boys and from 9.2 to $8.4 \%$ among girls ${ }^{(8)}$. However, when analysing the changes in this prevalence in different regions, one can find differences not only in the magnitude but also in the direction of changes. In South Asia, in the same period, the prevalence of underweight increased from $21 \cdot 1$ to $27 \cdot 1 \%$ among boys and from 20.5 to $26 \cdot 4 \%$ among girls. In contrast, in Polynesia, Malaysia and Southern Africa, it decreased sharply from about 20 to $5 \%^{(8)}$. In Central and Eastern Europe, the percentage of underweight decreased from $4 \%$ in the 1970 s to $0.5 \%$ in the year 2016 , but it did not change in Northwest and Southwest Europe ${ }^{(8)}$.

In European countries, the prevalence of underweight also fluctuated. In Spain, in 2004-2010, the prevalence of underweight decreased from 9.5 to $8.3 \%$ in boys and from 9.3 to $7.9 \%$ in girls ${ }^{(10)}$. In France, in 2009-2013, the prevalence increased from $7 \cdot 1$ to $7 \cdot 3 \%$ among boys and from 12.0 to $16.7 \%$ among girls ${ }^{(11)}$. In Russia, in the period 1992-1998, the percentage of underweight decreased from 9.0 to $7.7 \%$ among boys, while among girls it almost doubled (from 4.9 to $8.6 \%)^{(12)}$ (Table 1 ).

In Poland the prevalence of underweight is now estimated at about $10 \%$ of the population of children and adolescents. The highest percentage of underweight children and adolescents (about 14\%) is found in central (Łódźkie) and western (Lubuskie Province) Poland, and the lowest (about 9\%) in Mazowieckie (central Poland) ${ }^{(13)}$. The figures can differ significantly when broken down for girls and boys. For example, in the Lubelskie Voivodeship (eastern Poland), the prevalence of underweight among 7-20-year-old girls between 1986 and 2006 increased from about 13 to $16 \%$, while among boys it decreased from 10 to $8 \%^{(14,15)}$. In Łódź (the third largest city in central Poland, with about
750000 inhabitants), between 1977 and 2004 the prevalence of underweight among boys increased from $7 \cdot 2$ to $12 \cdot 1 \%$ and among girls from $11 \cdot 0$ to $20 \cdot 2 \%^{(16)}$ (Table 1 ).

It should be noted that the observed increase in the prevalence of underweight occurred in Poland in the period of political transformation. The 1970s and 1980s were a period of economic collapse in Poland ${ }^{(17)}$. It was only in the period 2002-2005 that Poland returned to a path of economic growth which was connected with preparations for the integration with the European Union. Polish accession to the European Union in 2004 resulted in the opening of borders and the intense westernization of the country ${ }^{(3,18)}$.

However, the most commonly used indicator in the assessment of underweight, overweight and obesity, i.e. BMI, has been increasingly criticized since it is calculated on the basis of mass and body height, so its value does not explain which of the body components (adipose tissue, muscle tissue, skeleton) affects the body weight ${ }^{(19)}$. Despite this, BMI is commonly used in epidemiological research on populations to diagnose too low or too high body weight in relation to body height. This is the result of the fact that the measurement of body mass and height, which is necessary to calculate this indicator, is simple, fast, cheap and noninvasive as well. Techniques that accurately measure body fat such as dual energy X-ray absorptiometry are expensive and rarely used in clinical practice ${ }^{(20)}$.

Several criteria classification of BMI have been proposed according to sex and age for children and adolescents, however there is not a criterion for classification of weight status in this type of population that is universally accepted. The most widely used criteria are those recommended by the US Centers for Disease Control and Prevention (CDC), the International Obesity Task Force (IOTF) $^{(21)}$ and (slightly less frequently) the $\mathrm{WHO}^{(22)}$. The decision of determining which cut-off points to use is always taken by researchers and clinicians ${ }^{(23)}$. 
The aim of the present study was to determine the changes in the prevalence of underweight among 3-18year-old girls and boys living in Kraków that occurred between the populations examined in 1983 and 2010. In addition, differences in the prevalence of underweight were analysed depending on the cut-off point used: CDC or IOTF.

\section{Materials and methods}

\section{Participants}

The children and adolescents analysed in the present study were included in a cross-sectional survey conducted in randomly selected kindergartens and schools in Kraków, Poland, in 2010. This city is one of the biggest in Poland (second most populated with almost 800000 inhabitants) who are a good representation of the Polish population from other big cities.

The analysis comprised 5245 children ( 2579 boys and 2666 girls) aged $3-18$ years. The cohort was a representation of each of the four traditional residential districts of Kraków. In order to provide a representative sample, the selection of units for testing (schools and classrooms) was determined at random. All types of schools were taken into account (kindergarten, primary school, secondary school, basic vocational school, technical school, high school), as well as their location in Kraków. All analysed schools and kindergartens of Kraków were chosen by two-stage lottery, using the urn randomization without replacement method.

The 2010 examinations were conducted according to the procedures in force, i.e. with the consent of the Bioethics Committee at the Regional Medical Association in Kraków (No. 26/KBL/OIL/2007) and the consent of children's parents or their legal guardians. The calendar age of the participants, calculated as the difference between the date of the survey and the birth date, expressed as a decimal fraction, was a basis for classifying them as one of sixteen age groups, e.g. the participants aged 5.00-5.99 years were in the group of 5.5-year-old children.

The data from the 2010 survey series were compared with the results from the previous survey series conducted in the year 1983. The sample size of the previous series was 6261 ( 3125 boys and 3136 girls) ${ }^{(24)}$. These studies were carried out under the project titled 'The Child of Krakow'. The aim of these studies was to monitor the level of development of children and adolescents from Kraków. This research, similarly to 2010, was conducted in randomly selected kindergartens and schools. The measurements were made in the same way as described below. Moreover, the composition of research teams remained almost the same as in 2010.

\section{Measurements}

All the survey series were conducted by a team of academic researchers of the Department of Anthropology and Department of Physiotherapy at the University School of Physical Education in Kraków. The measurements were taken according to Martin's technique ${ }^{(25)}$ using a set of tools made by the Swiss manufacturer Sieber Hegner Machines SA. For the measurements, the participants removed their shoes, emptied their pockets and wore light indoor clothing. Height was measured to the nearest $0 \cdot 1 \mathrm{~cm}$. In the 2010 survey series, Body Composition Analyzer scales, type BC-418 MA (Tanita, Japan), were used to measure body weight to the nearest $0.01 \mathrm{~kg}$. With this measurement BMI was calculated as weight $/$ height ${ }^{2}\left(\mathrm{~kg} / \mathrm{m}^{2}\right)$.

\section{BMI classification}

The estimations of the prevalence of underweight were based on the cut-off points of the $\operatorname{IOTF}^{(26)}$ and $\mathrm{CDC}^{(27)}$ values. The IOTF cut-off points for overweight and underweight were developed using the data from nationally representative surveys that were implemented from 1963 to 1993 in six high- and upper-middle-income countries (200 000 children in Brazil, Great Britain, Hong Kong, the Netherlands, Singapore and the USA). Regression procedures were used to create smoothed BMI curves that generated adult cut-off points for underweight of 3, 2 and 1 grade of 16,17 and $18.5 \mathrm{~kg} / \mathrm{m}^{2}$, and were extrapolated back to appropriate age of childhood. Reference values are given in 6-month intervals ${ }^{(26,28,29)}$.

The CDC growth charts were developed on the basis of data from five nationally representative surveys in the USA from 1963 to 1994 ( 30000 children) ${ }^{(29)}$. In the CDC scheme, BMI values below the 3 rd percentile and between the $3 \mathrm{rd}$ and 5 th percentile were taken as criterion for underweight ${ }^{(13,27)}$.

\section{Age groups}

In a detailed analysis, children and adolescents were divided into three age groups according to Bogin and Varia ${ }^{(30)}$ as follows:

1. childhood (including boys and girls aged $3-6$ years);

2. juvenile (including boys aged 7-12 years and girls aged 7-10 years); and

3. adolescent (including boys aged over 12 years and girls aged over 10 years).

This classification is the result of the difference in the tempo of maturation ${ }^{(30)}$.

\section{Statistical analysis}

In order to determine the underweight tendency, the series from 2010 was compared with that from 1983. The statistical significance of differences was assessed by the $\chi^{2}$ test. The statistical analyses were made using the statistical software package Statistica version 12.0.

\section{Results}

Supplemental Table S1 (see online supplementary material) presents the prevalence of underweight among boys from the two series of studies. The prevalence of 
Trends in prevalence of underweight

underweight in boys decreased in almost all age groups between 1983 and 2010 regardless of the cut-off points used. Using the IOTF criteria the frequency of underweight decreased from 8.9 to $7.5 \%$ (by 1.4 percentage points (pp)) and according to the CDC criteria from 5.9 to $4.6 \%$ (by $1.3 \mathrm{pp}$ ). The biggest decrease in the prevalence of underweight was found in 9.5-year-olds. In this age group, the frequency of underweight estimated by the IOTF method decreased from 13.2 to $4.0 \%$ (about $9 \mathrm{pp}$ ) and by slightly over $8 \mathrm{pp}$ according to the CDC method (from 9.3 to $0.9 \%$ ). The exceptions were children aged 5.5 , 11.5 and $16.5-18.5$ years, where an increase in the prevalence of underweight was found, the highest being in boys aged 16.5 years. In the last group, the prevalence of underweight increased from 4.1 to $12.4 \%$ (8.3 pp) according to the IOTF and from 4.5 to $12.4 \%$ according to the CDC (7.9 pp). For the boys from the 1983 series the percentage of underweight estimated by the IOTF method was $3 \mathrm{pp}$ higher compared with the CDC method and was respectively $8.9 \% v .5 .9 \%$. A similar situation took place in a series of surveys from 2010 where the difference in percentages calculated using the two methods was $2.9 \mathrm{pp}$ and these rates were respectively $7.5 \% v .4 .6 \%$.

Supplemental Table S2 (see online supplementary material) shows the results of the underweight prevalence of girls from the two series of studies. The underweight prevalence determined by the IOTF cut-off decreased from $10.5 \%$ in 1983 to $10.4 \%$ in 2010, but if the CDC criteria were used, it decreased from 5.1 to $4.4 \%$. It seems that the decrease was less than it was in the case of the boys, i.e. by $0.1 \mathrm{pp}$ from the IOTF criteria and $0.7 \mathrm{pp}$ from the CDC. Analysis of the results obtained in individual age groups showed that in the girls aged 3.5-7.5 years (with the exception of 6.5-year-old girls) and in girls from 15.5 years, the percentage of those with underweight increased between 1983 and 2010. In the remaining age groups, the percentage of underweight children decreased. The biggest decline in the prevalence of underweight was found in 11.5-year-olds. In this age group, the underweight frequency according to the IOTF decreased from 20.3 to $9.6 \%$, while according to the CDC it decreased from 8.5 to $2.8 \%$, so it was respectively about $11 \mathrm{pp}$ and $6 \mathrm{pp}$ lower in 2010 than in 1983. Similar to the boys, the percentage of underweight girls estimated using the IOTF criteria was nearly twice as high as using the CDC criteria from both 1983 and 2010. In conclusion, it was found that according the IOTF criteria, the prevalence of underweight in girls was higher than in boys; on the other hand, using the CDC criteria it was shown that the prevalence of underweight in girls was slightly lower than in boys. Regardless of the method used, a reduction in the prevalence of underweight between the series of studies was showing.

Tables 2 and 3 show the prevalence of underweight in 1983 and 2010 among girls and boys in the age ranges proposed by Bogin and Varia ${ }^{(30)}$. Analysis in age groups showed that in boys, the frequency of underweight estimated using the IOTF cut-off increased slightly among

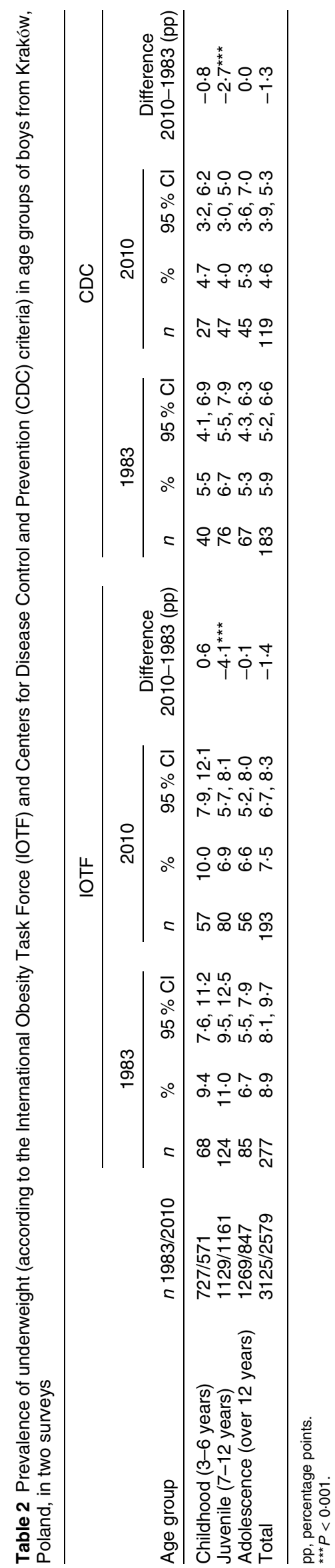




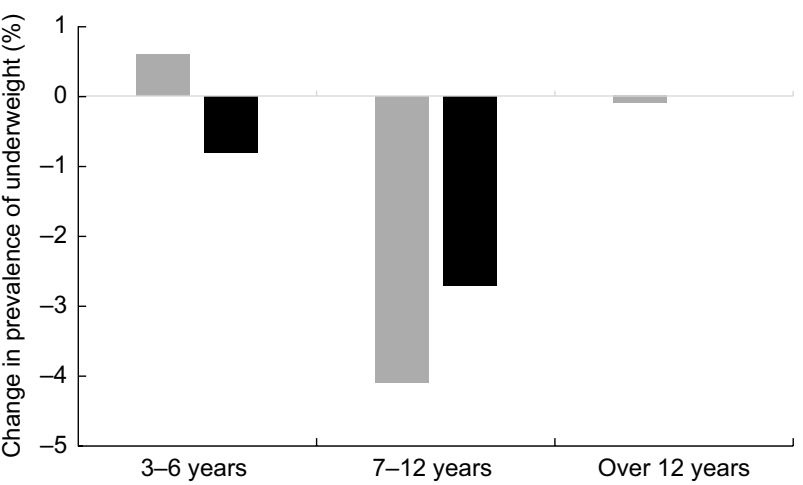

Fig. 1 Percentage changes in the prevalence of underweight, according to the International Obesity Task Force $(\square)$ and Centers for Disease Control and Prevention ( $\square$ ) criteria, between the two surveys (1983 and 2010) in boys aged 3-18 years by age group, Kraków, Poland

children from $9.4 \%$ in year 1983 to $10.0 \%$ in year 2010 , while it decreased among juveniles from 11.0 to $6.9 \%$ and among adolescents from 6.7 to $6.6 \%$. Using the CDC criteria showed in boys that the prevalence of underweight decreased among children from $5.5 \%$ in 1983 to $4.7 \%$ in 2010 and among juveniles from 6.7 to $4.0 \%$, but among adolescents it did not change. There was a statistically significant decrease in the prevalence of underweight only in the group of boys aged $7-12$ years using both the IOTF and CDC criteria $(P<0.004 ;$ Table 2, Fig. 1). A similar trend was found among the girls. Between years 1983 and 2010, in childhood, the prevalence of underweight increased from 6.9 to $8.6 \%$ when using the IOTF criteria and no changes were found when using the $\mathrm{CDC}$ criteria. Among juveniles and adolescents, regardless of the method used, the frequency of underweight decreased. According to the IOTF cut-off, the prevalence of underweight decreased in juveniles from 11.9 to $10.2 \%$ and in adolescents from 11.3 to $11.2 \%$. According to CDC criteria, the frequency decreased in juveniles from 7.0 to $4.4 \%$ and in adolescents from 4.7 to $4.5 \%$ (Table 3, Fig. 2). As in the case of boys, the largest change in the percentage of underweight girls was observed in the juvenile period, and the greater and statistically significant change in the examined period was found when using the CDC criteria $(P<0.022)$. The smallest differences between the series of surveys took place in the group of the oldest girls regardless of the method of underweight evaluation (Fig. 2).

\section{Discussion}

The analysis of changes in the prevalence of underweight in the Kraków children and adolescents showed that from 1983 to 2010 the prevalence decreased slightly. Among boys, regardless of the method used (CDC, IOTF), the decrease in the prevalence of underweight was just over 1 pp. In girls, using the CDC method, the prevalence of 


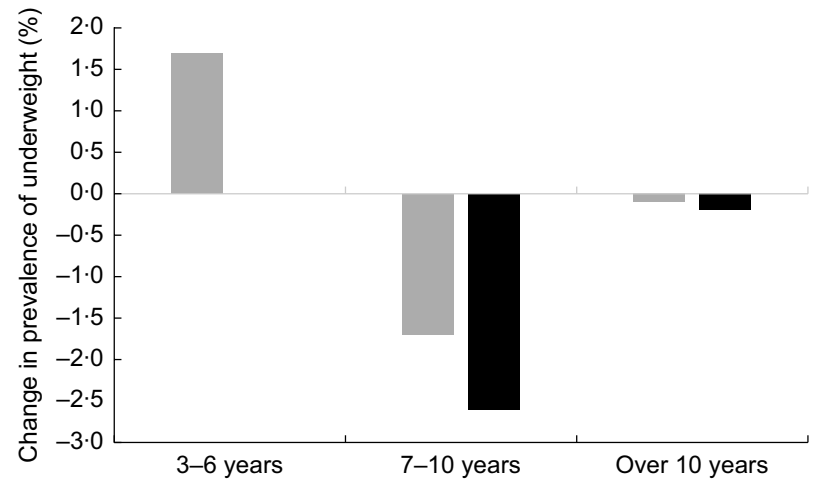

Fig. 2 Percentage changes in the prevalence of underweight, according to the International Obesity Task Force $(\square)$ and Centers for Disease Control and Prevention ( $\square$ ) criteria, between the two surveys (1983 and 2010) in girls aged 3-18 years by age group, Kraków, Poland

underweight decreased by almost 1 pp. According the IOTF method, it was lower by only $0 \cdot 15 \mathrm{pp}$. After separating the age groups, it was shown that the prevalence of underweight among boys and girls, determined using the IOTF cut-off points, increased during childhood, while in the juvenile and adolescence periods it decreased. Using the CDC method, the prevalence of underweight in boys and girls decreased in almost all age groups. The biggest differences between 1983 and 2010 were found among boys and girls in the juvenile period.

The end of the 20th century saw a clear increase in the prevalence of overweight and obesity among adults, children and adolescents in the USA and many Western European countries, becoming an important public health problem $^{(31,32)}$. As a result, the problem of low body mass in relation to height was somewhat overlooked, although overweight and underweight are often co-occurring even within one family ${ }^{(33)}$. Further studies have shown, however, that the phenomenon of child malnutrition is a significant problem, especially in developing countries. Its consequence, underweight ${ }^{(7,34)}$, contributes to the development of osteoporosis, growth disorders and pubertal disorders ${ }^{(33)}$.

Pilot studies estimating the prevalence of underweight among children predicted that from 1990 to 2015 it would decrease in the world from over $26 \%$ to almost $18 \%$. Small changes were to take place in developed countries (a fall from 1.6 to $0.9 \%$ ), while in developing countries the drop in the prevalence of underweight was predicted to be from more than $30 \%$ to about $20 \%{ }^{(35)}$. Based on information from over 200 countries and areas, it has been shown that changes in the prevalence of underweight in children and adolescents between 1975 and 2016 were lower than forecast. The prevalence of underweight among girls had decreased from 9.2 to $8.4 \%$ and among boys from 14.8 to $12.4 \%$. As predicted, the largest decrease in that period occurred in developing countries - Micronesia, Polynesia and Southern Africa. In South Asia, however, the prevalence of underweight increased, from $20 \cdot 5$ to $26.4 \%$ among girls and from $21 \cdot 1$ to $27 \cdot 1 \%$ among boys, which may be the result of a rapid increase in population in this area ${ }^{(8)}$. This direction of change, however, was not characteristic for all the regions on this part of the continent. In eastern China, between 1985 and 2010, the prevalence of underweight was found to have decreased both in boys and girls ${ }^{(7)}$, and a similar trend in this region was found between 2009 and $2015^{(34)}$. The authors of that research explain the negative trend by an improvement in living conditions, especially among young women, whom, thanks to this, are more likely to breast-feed their babies and later are able to provide proper nutrition ${ }^{(34)}$.

A decrease in the prevalence of underweight was also found in the countries of North and South America. In Brazil, between 1974 and 1997, among 6-18-year-old children and adolescents, this prevalence decreased from almost $15 \%$ to about $9 \%$, which was the result of improvements in the material condition of the population. The beginning of the 20th century brought a further decline in the prevalence of underweight in that country and the trend continued in the following years ${ }^{(36)}$. In the USA over a similar period, the prevalence of underweight decreased from about $5 \%$ to about $3 \%{ }^{(12,37)}$.

In Europe, changes in the prevalence of underweight in individual countries have also occurred in different directions. In France, in 2006-2013, the prevalence increased from $7 \cdot 1 \%$ in boys and $12.0 \%$ in girls to 7.4 and $16.7 \%{ }^{(11)}$, respectively. A similar trend was found in Spain in 1992-2004, but in subsequent years (2004-2010) the prevalence decreased ${ }^{(10,38)}$. An increase in the prevalence of underweight was also found in Sweden, Greece ${ }^{(33)}$ and Portugal ${ }^{(39)}$. In Tuscany, however, this figure decreased in 2000-2006 ${ }^{(40)}$, and in Great Britain in the years 1998-2006 it was fluctuating ${ }^{(10)}$.

In Russia in the years 1992-1998, just after the collapse of the Soviet Union and the Eastern European bloc, the prevalence of underweight increased from 6.9 to $8.1 \%$. It was the result of a decline in gross domestic product (GDP) during 1990-1997 in that country by over $50 \%$, a progressive barter exchange, unstable budgetary constraints and, as a result, a financial crisis of the state ${ }^{(41)}$. In the Czech Republic, the prevalence of underweight in the same period did not change ${ }^{(33)}$.

In Poland, the analysed period was a time of rapid changes and socio-economic transformations. In the 1980s, the economy collapsed. As a result, the average annual GDP growth in the same period was only $0.5 \%(17,42)$. The next decade also started with an economic crisis (GDP in 1990 fell by $8 \%$ and in 1991 by another $7 \%$; in 1989 the GDP per capita was about \$US 7700/year) which was caused by the costs of socio-economic transformation ${ }^{(18,42)}$. However, in the years 1992-1994 the average annual GDP growth in Poland amounted to almost $4 \%$, and in the years 1995-1997 it was almost 7\%. The abandonment of economic reforms in the late 1990s contributed to a decline in GDP to 
$2 \%$, but in subsequent years (2002-2005) internal demand increased, and intensive preparations for integration with the European Union brought Poland back to a path of economic growth, with GDP per capita in 2010 exceeding \$US $18000^{(42-44)}$. The socio-economic transformation in Poland was also reflected in other measures of well-being, e.g. real minimum wages showed systematic growth from \$US 4000/ year in 1992 year to near \$US 9000/year in $2010^{(45)}$. However, the unemployment rate varied significantly in the analysed period. In 1990 it was about $6 \%$, and then increased until 1993, when it amounted to $16 \%$. The beginning of the 21st century brought another increase in unemployment up to 2002, when it amounted to almost $20 \%$. In 2010, the unemployment rate was about $10 \%{ }^{(46)}$.

Despite such rapid and dynamic socio-economic changes in Poland, it was shown that the prevalence of underweight among Cracovian children and youth decreased only slightly during that period (1983-2010). This may indicate that economic changes in the country had not contributed to the rapid impoverishment of society, and the improvement of material conditions and the emergence of a new social class of affluent people concerned only a small group in the population ${ }^{(14)}$. The lack of changes in the prevalence of underweight may also be the result of the fact that the research was conducted among students of schools in the city which is the second largest city in Poland. Poverty that may result in the increase in the prevalence of underweight is a more frequent phenomenon in rural areas with a low degree of urbanization. These are areas with a low number of workplaces and a large part of the population remains unemployed. In addition, people living in poorly urbanized areas are characterized by a lower level of education, hence their considerably lower incomes. Undoubtedly, also the family structure (many children) in poorly urbanized areas may contribute to the increase in poverty, which may result in a higher prevalence of underweight ${ }^{(47,48)}$. A similar phenomenon was found in Warsaw adolescents between 1971 and 2006. In Warsaw (the capital of Poland; 1.7 million inhabitants) the prevalence of underweight decreased in boys from $7.9 \%$ in 1971 to $6.4 \%$ in 2006, but in girls increased from 10.4 to $13.9 \%{ }^{(49)}$. We suppose that the changes observed in girls could be the result of the westernization process observed also in our research. In Łódź between 1977 and 2004 the prevalence of underweight among boys increased from $7 \cdot 4$ to $12 \cdot 1 \%$ and among girls from 11.0 to $20 \cdot 2 \%{ }^{(16)}$. The increase in percentage of underweight among children from tódź could be explained by the failure of the textile industry after 1989, resulting in high unemployment figures in this region (16\% unemployment in Łódź in 1995, while in Kraków it was 6\%) ${ }^{(46)}$.

On the basis of the obtained results, it was additionally found that in both 1983 and 2010 the prevalence of underweight, determined by means of the cut-off points proposed by the IOTF, was higher among girls than among boys, but using the CDC method, it was found that the prevalence of underweight among girls and boys was similar. In childhood, the prevalence was higher in boys than in girls, whereas in the juvenile and adolescence periods it was higher among girls, which corresponds to results obtained in other regions of Poland ${ }^{(15,49,50)}$. A similar trend was also found in many European countries and on other continents. In France, the problem of underweight concerned boys during childhood and early adolescence. In girls, the prevalence of underweight increased with age and affected late and early adolescents ${ }^{(11)}$. Also, in Tuscany (Italy), the prevalence of underweight among children and adolescents increased with age and was higher in girls, especially in the older age groups ${ }^{(40)}$. A similar trend was observed in Ukraine $^{(47)}$, Bulgaria ${ }^{(19)}$, Sweden ${ }^{(51)}$, Japan ${ }^{(4)}$, China and Hong Kong ${ }^{(7)}$, and Brazil ${ }^{(52)}$. Higher prevalence of underweight in older age groups was also found in Russia, but this prevalence was higher among boys ${ }^{(12,39)}$.

The reported higher prevalence of underweight in girls than boys is most likely the effect of westernization observed in many countries, which caused a change in lifestyle, canons of the optimal body frame, and mass media pressures on contemporary women to have an unrealistically slim figure ${ }^{(53)}$. Westernization usually brings stabilization or even a decrease in the prevalence of overweight among girls and the process of their slimming has been observed in many European countries. This phenomenon was recorded in Switzerland ${ }^{(54)}$, the Czech Republic ${ }^{(55)}$, Lithuania $^{(53)}$ and in our own research ${ }^{(56)}$.

The growing prevalence of underweight, especially among girls in older age groups, may paradoxically be a result of preventive measures aimed at reducing the percentage of children who are overweight. It turns out that those with normal body mass are more responsive to preventive measures promoting weight loss, and their actions may often lead to underweight ${ }^{(31)}$. It is perhaps also related to the fact that girls more often than boys, under the influence of environmental factors, undertake even occasional pro-health activities ${ }^{(57,58)}$. It should also be added that parents of underweight children often perceive them as children with normal body mass. Moreover, insufficient body mass is more often accepted and preferred by daughters than by sons ${ }^{(59)}$. Some researchers link the increase in the prevalence of underweight to earlier puberty. This period is associated with changes in the body structure and composition ${ }^{(19,33)}$. In our own research, this phenomenon could be an additional element conducive to an increase in the prevalence of underweight in older age groups of girls. Both girls and boys from the 2010 series showed the signs of pubertal development earlier than children from the 1983 series $^{(56,60)}$.

Analysis of the prevalence of underweight by the two methods showed that these frequencies were higher using the cut-off points proposed by the IOTF than those proposed by the CDC. Similar results were obtained in Ukraine $^{(47)}$. In Iran, there were also significant differences in the prevalence of underweight when using two different criteria for its assessment (CDC $v$. 5th percentile) ${ }^{(61)}$. 
Therefore, the selection of an appropriate method to assess underweight in children and adolescents becomes a significant problem during screening tests.

Our study reported more cases of underweight using the IOTF method compared with the CDC method. One of the reasons for these differences is the fact that the IOTF method includes three degrees of underweight (BMI of 16,17 and $\left.18.5 \mathrm{~kg} / \mathrm{m}^{2}\right)^{(62)}$ while in the CDC method there are only two levels (below the 3rd percentile and between the $3 \mathrm{rd}$ and 5 th percentiles).

Differences in the approach to determining the cut-off points and the number of levels of adiposity result in differences in the number of children with underweight depending on the method adopted. For example, in 11.5-year-old girls, the numbers of underweight girls determined by the IOTF and CDC methods were twenty and forty-eight in 1983, and twenty-one and six in 2010, respectively. In this group, three levels of underweight in the IOTF method include BMI values from 13.15 to $15.32 \mathrm{~kg} / \mathrm{m}^{2}$. In the CDC method, two levels of thinness are in the range 13.94 to $14.45 \mathrm{~kg} / \mathrm{m}^{2}$. Therefore, the range for the CDC method is narrower and a smaller number of children qualify for the underweight group.

The problem of overestimation of the prevalence of underweight in children with the IOTF method in relation to CDC was also noted by Tuan and Niklas ${ }^{(29)}$. The total difference in the prevalence of underweight among children and adolescents from China, Indonesia and Vietnam was respectively 6, 10 and 13 pp in boys and 10, 13 and 19pp in girls. In a study conducted by Partap et al. ${ }^{(63)}$ in children aged 6-18 years from Malaysia using three methods (i.e. CDC, IOTF and WHO), differences were noted due to the assumed BMI references. The highest percentage of underweight was observed using the IOTF method at $13 \cdot 1 \%$ (CDC $7.9 \%$ and WHO $4.6 \%$ ). These differences occurred in both boys and girls, and were, respectively: in boys (12.7 pp, $9.4 \mathrm{pp}, 5.5 \mathrm{pp})$ and in girls (16.0 pp, $7.9 \mathrm{pp}, 4.3 \mathrm{pp})$.

In our study, despite the differences in the number of underweight children and regardless of the method used, the trend was maintained in most age groups. Our analysis of the trend of the occurrence of underweight indicated differences in the size of changes depending on the cutoff points used. It indicates that in the assessment of the trend, the adopted method of underweight evaluation is less important than in the case of determining the occurrence of malnutrition among children and adolescents. However, using various methods and various cut-off points is a problem in global monitoring of the prevalence of underweight as well as in tracking national trends. Therefore, we postulate that the prevalence of underweight should always be evaluated by several methods.

The significance of the present report is that the study includes two series of children and adolescents measured in Kraków in the same districts and by the same team. Additionally, our centre was the first which presented changes in the frequency of underweight estimated based on two independent methods. Our study has a few limitations. First is the type of study (not longitudinal). Second, the possibility of potential selection bias cannot be ruled out in a cross-sectional study spread across time and region. However, we tried to minimize the sampling bias. We compared individuals of same age group entering similar standards at two different points of time. We selected all students from randomly selected sections of a standard, with a $100 \%$ response rate from the first series (1983) and about $85 \%$ from the second one (2010).

\section{Acknowledgements}

Financial support: The study survey was part of a project financed by the Polish Council for Science and Technology (grant number NN404 177 035) and by University School of Physical Education in Krakow (grant number 204/KA/206). The funders had no role in the design, analysis or writing of this article. Conflict of interest: The authors declare that they have no conflict of interest. Authorship: M.K., R.W. and R.Z. contributed to the study design. All authors oversaw the participant recruitment and data collection. M.K. and R.W. performed the statistical analysis for the manuscript and wrote the manuscript. All authors contributed to a critical review of the manuscript during the writing process. Ethics of buman subject participation: This study was conducted according to the guidelines laid down in the Declaration of Helsinki and all procedures involving human subjects were approved by Bioethics Committee at the Regional Medical Association in Kraków (No. 26/ $\mathrm{KBL} / \mathrm{OIL} / 2007$ ) and the consent of children's parents or their legal guardians.

\section{Supplementary material}

To view supplementary material for this article, please visit https://doi.org/10.1017/S1368980019001319

\section{References}

1. Ho NS, Olds T, Schranz N et al. (2017) Secular trends in the prevalence of childhood overweight and obesity across Australian states: a meta-analysis. I Sci Med Sport 20, 480-488.

2. Lobstein T, Rugby N \& Leach R (2005) Obesity in Europe - 3. Brussels: International Obesity Task Force.

3. Mazur A, Klimek K, Telega G et al. (2014) Ten-year secular trend of overweight and obesity in school children in southeastern Poland. Ann Agric Environ Med 21, 634-638.

4. Shirasawa T, Ochiai H, Nanri H et al. (2015) Trends of underweight and overweight/obesity among Japanese schoolchildren from 2003 to 2012, defined by body mass index and percentage overweight cutoffs. J Epidemiol 25, 482-488.

5. Whitaker RC, Wright JA, Pepe MS et al. (1997) Predicting obesity in young adulthood from childhood and parental obesity. $N$ Engl J Med 337, 869-873.

6. Doak CM, Adair LS, Monteiro C et al. (2000) Overweight and underweight coexist within households in Brazil, China and Russia. J Nutr 130, 2965-2971. 
7. Zhang YX, Wang ZX, Wang M et al. (2015) Prevalence of thinness among children and adolescents in Shandong, China. Eur J Nutr 55, 809-813.

8. NCD Risk Factor Collaboration (NCD-RisC) (2017) Worldwide trends in body-mass index, underweight, overweight, and obesity from 1975 to 2016: a pooled analysis of 2416 population-based measurement studies in 128.9 million children, adolescents, and adults. Lancet $\mathbf{3 9 0}$, 2627-2642.

9. NCD Risk Factor Collaboration (NCD-RisC) (2016) Trends in adult body-mass index in 200 countries from 1975 to 2014: a pooled analysis of 1698 population-based measurement studies with 19.2 million participants. Lancet 387, 1377-1396.

10. Martínez-Vizcaí V, Solera Martínez M, Natario Pacheco B et al. (2012) Trend in excess of weight, underweight and adiposity among Spanish schoolchildren from 2004 to 2010: the Cuenca study. Public Health Nutr 15, 2170-2174.

11. Vanhelst J, Baudelet JB, Fardy PS et al. (2017) Prevalence of overweight, obesity, underweight and normal weight in French youth from 2009 to 2013. Public Health Nutr 20 , 959-964.

12. Wang Y, Monteiro C \& Popkin BM (2002) Trends of obesity and underweight in older children and adolescents in the United States, Brazil, China, and Russia. Am J Clin Nutr 75, 971-977.

13. Grajda A, Kułaga Z, Gurzkowska B et al. (2011) Regional differences in the prevalence of overweight, obesity and underweight among polish children and adolescent. Med Wieku Rozwoj 15, 258-263.

14. Wasiluk A, Saczuk J \& Zalech M (2013) Underweight, overweight, and obesity in girls at the age of 7-19 years from the Lubelskie Province in the years 1986-2006. Pediatr Endocrinol 19, 11-17.

15. Wasiluk A \& Saczuk J (2015) Underweight, overweight, and obesity in boys and girls at the age of 7-18 years from eastern Poland in the years 1986-2006. Studia Medyczne 31, 99-105.

16. Ządzińska E, Rosset I, Kozieł S et al. (2012) Frequency of under- and overweight among children and adolescents during the economic transition in Poland. Homo 63, 216-232.

17. Charzewska J, Rogalska-Niedźwiedź M, Chojnowska Z et al. (1995) Społeczne uwarunkowania żywienia młodzieży $w$ latach 1982-1991. Prace Instytutu Żywności i Żywienia no. 71. Warszawa: Instytut Żywienia i Żywności.

18. Piech K (2003) Cykl koniunkturalny Polski a światowy cykl koniunkturalny - wnioski dla polskiej polityki stabilizacyjnej. In Przemiany i perspektywy polskich przedsiębiorstw $w$ dobie integracji z Uniq Europejska, pp. 141-155 [K Piech and G Szczodrowski, editors]. Warszawa: Instytut Wiedzy.

19. Mladenova A \& Andreenko E (2015) Prevalence of underweight, overweight, general and central obesity among 8-15-years old Bulgarian children and adolescents. Nutr Hosp 31, 2419-2427.

20. Okorodudu DO, Jumean MF, Montori VM et al. (2010) Diagnostic performance of body mass index to identify obesity as defined by body adiposity: a systematic review and meta-analysis. Int J Obes (Lond) 34, 791-799.

21. Minghelli B, Nunes C \& Oliveira R (2014) Body mass index and waist circumference to define thinness, overweight and obesity in Portuguese adolescents: comparison between CDC, IOTF, WHO references. Pediatr Endocrinol Rev 12, 35-41.

22. de Onis M, Onyango AW, Borghi E et al. (2007) Development of a WHO growth references for school-aged children and adolescents. Bull World Health Organ 85, 660-667.

23. Janssen I, Katzmarzyk PT, Srinivasan SR et al. (2005) Utility of childhood BMI in the prediction of adulthood disease: comparison of national and international references. Obes Res 13, 1106-1115.
24. Chrzanowska M, Gołąb S, Bocheńska Z et al. (1988) The child of Cracow. The level of the biological development in the Cracow children and youth (Dziecko krakowskie. Poziom rozwoju biologicznego dzieci i młodzieży miasta Krakowa). Wydawnictwo Monograficzne AWF no. 34. Kraków: Akademia Wychowania Fizycznego.

25. Martin R \& Saller K (1957) Lehrbuch der Antropologie. Stuttgart: Fisher.

26. Cole TJ, Flegal KM, Nicholls D et al. (2007) Body mass index cut offs to define thinness in children and adolescents: international survey. BMJ 335, 194.

27. Kuczmarski RJ, Ogden CL, Guo SS et al. (2002) 2000 CDC growth charts for the United States: methods and development. National Center for Health Statistics Vital Health Stat 11 issue 246, 1-190.

28. Mak KK \& Tan SH (2012) Underweight problem in Asia children and adolescents. Eur J Pediatr 171, 779-785.

29. Tuan NT \& Nicklas TA (2009) Age, sex and ethnic differences in the prevalence of underweight and overweight, defined by using the CDC and IOTF cut points in Asian children. Eur J Clin Nutr 63, 1305-1312.

30. Bogin B \& Varia C (2017) Evolution of human life history. In Evolution of Nervous Systems, 2nd ed., vol. 4, pp. 37-50 [J Kaas, editor]. Cambridge, MA: Academic Press.

31. de Ruiter I, Olmedo-Requena R, Sánchez-Cruz JJ et al. (2017) Trends in child obesity and underweight in Spain by Birth year and age, 1983 to 2011. Rev Esp Cardiol (Engl Ed) 70, 646-655.

32. Sjöberg A, Lissner L, Albertsson-Wikland $\mathrm{K}$ et al. (2008) Recent anthropometric trends among Swedish school children: evidence for decreasing prevalence of overweight in girls. Acta Paediatr 97, 118-123.

33. Lazzeri G, Rossi S, Kelly C et al. (2014) Trends in thinness prevalence among adolescents in ten European countries and the USA (1998-2006): a cross-sectional survey. Public Health Nutr 17, 2207-2215.

34. Chen J, Chen W, Zeng G et al. (2016) Secular trends in growth and nutritional outcomes of children under five years old in Xiamen, China. Int J Environ Res Public Health 13, E1104.

35. de Onis, Blössner M, Borghi E et al. (2004) Estimates of global prevalence of childhood underweight in 1990 and 2015. JAMA 291, 2600-2606.

36. Flores LS, Gaya AR, Petersen RDS et al. (2013) Trends of underweight, overweight, and obesity in Brazilian children and adolescents. J Pediatr (Rio J) 89, 456-461.

37. Yanovski JA (2018) Trends in underweight and obesity: scale of the problem. Nat Rev Endocrinol 14, 5-6.

38. Martínez-Vizcaí V, Sánchez López M, Maya Martínez P et al. (2009) Trend in excess weight and thinness among Spanish schoolchildren in the period 1992-2004: the Cuenca study. Public Health Nutr 12, 1015-1018.

39. Khasnutdinova SI \& Gribovski AM (2010) Prevalence of stunting, underweight, overweight and obesity in adolescents in Velsk district, north-west Russia: a cross-sectional study using both international and Russian growth references. Public Health 124, 392-397.

40. Lazzeri G, Rossi S, Pammolli A et al. (2008) Underweight and overweight among children and adolescents in Tuscany (Italy). Prevalence and short-term trends. I Prev Med Hyg 49, 15-21.

41. Stankiewicz W (2006) Konsekwencje zmian politycznoekonomicznych w Rosji po upadku komunizmu. Środkowoeuropejskie studia polityczne 2, 95-118.

42. Kaliński J (2017) Fazy wzrostu gospodarki polskiej po 1918 roku. Optimum Studia ekonomiczne 1, 65-81.

43. Index Mundi (2018) Poland GDP per capita (PPP). https:// www.indexmundi.com/poland/gdp_per_capita_(ppp).html (assessed June 2018).

44. Krakowińska E (2007) Społeczne skutki transformacji gospodarki - polska bieda. In Czynniki wzrostu gospodarczego $w$ Polsce 2006+, pp. 91-231 [K Ryc \& M Dusza, editors]. 
Warszawa: Wydawnictwo Naukowe Wydziału Zarządzania Uniwersytetu Warszawskiego.

45. Organisation for Economic Co-operation and Development (2011) Real minimum wages - OECD.Stat. https://stats.oecd. org/Index.aspx/DataSet. Code (accessed November 2013).

46. Central Statistical Office of Poland (GUS) (2017) Unemployment rate 1990-2016. https://stat.gov.pl/en/topics/ labour-market/registered-unemployment/unemploymentrate-1990-2018,3,1.html (accessed April 2017).

47. Dereń K, Nyankovskyy S, Nyankovska O et al. (2018) The prevalence of underweight, overweight and obesity In children and adolescents from Ukraine. Sci Rep 8, 3625 .

48. GUS - Główny Urząd Statystyczny (2011) Ubóstwo w Polsce w 2010 roku. https://stat.gov.pl/cps/rde/xbcr/gus/wz_ubostwo_ w_polsce_2010.pdf (accessed July 2011).

49. Chabros E, Charzewska J, Wajszczyk B et al. (2011) Frequency of underweight in Warsaw adolescents in the last 3 decades. Probl Hig Epidemiol 92, 99-102.

50. Saczuk J \& Wasiluk A (2014) Underweight, overweight and obesity in boys and girls at the age of 7-18 years from the Podlaskie Province (Poland) in the years 1986 and 2006 Baltic J Health Phys Act 6, 259-266.

51. Eriksson M, Lingfors H \& Golsäter M (2018) Trends in prevalence of thinness, overweight and obesity among Swedish children and adolescents between 2004 and 2015. Acta Paediatr 107, 1818-1825.

52. de Assis MAA, Rolland-Cachera MF, Grosseman S et al. (2005) Obesity, overweight and thinness in schoolchildren of the city of Florianópolis, southern Brazil. Eur J Clin Nutr 59, 1015-1021.

53. Tutkuviene J (2005) Sex and gender differences in secular trend of body size and frame indices of Lithuanians. Anthropol Anz 63, 29-44.
54. Aeberli I, Ammann RS, Knabenhans M et al. (2010) Decrease in the prevalence of paediatric adiposity in Switzerland from 2002 to 2007. Public Health Nutr 13, 806-811.

55. Vignerová J, Humeníkowá L, Paulová M et al. (2008) Prevalence of overweight, obesity and low weight In the Czech child population up to 18 years of age in the last 50 years. J Public Health 16, 413-420.

56. Kowal M, Kryst $\mathrm{E}$, Woronkowicz A et al. (2014) Long-term changes in body composition and prevalence of overweight and obesity in girls (aged 3-18 years) from Kraków (Poland) from 1983, 2000 and 2010. Ann Hum Biol 41, 415-427.

57. Wells JCK, Nesse RM, Sear R et al. (2017) Evolutionary public health: introducing the concept. Lancet 390, 500-509.

58. Ślusarka B, Zarzycka D, Wrońska I (2015) Differentiation of behavioral health factors among students depending on selected socio-demographic, environmental and cultural factors. J Educ Health Sport 5, 99-108.

59. Júlíusson PB, Roelatns M, Markestad T et al. (2011) Parental perception of overweight and underweight in children and adolescents. Acta Paediatr 100, 260-265.

60. Kowal M, Kryst $€$, Woronkowicz A et al. (2015) Time trends in BMI, body fatness, and adiposity rebound among boys from Kraków (Poland) from 1983 to 2010. Am J Hum Biol 27, 646-653.

61. Kelishadi R, Ardalan G, Gheriatmand R et al. (2007) Thinness, overweight and obesity in a national sample of Iran children and adolescents: CASPIAN Study. Child Care Health Dev $\mathbf{3 4}$, 44-54.

62. Cole T, Bellizzi MC, Flegal KM et al. (2000) Establishing a standard definition for child overweight and obesity worldwide: international survey. BMJ 320, 1240-1243.

63. Partap U, Young EH, Allotey P et al. (2017) The use of different international references to assess child anthropometric status in a Malaysian population. J Pediatr 190, 63-68. 